\title{
Containing the Atom:
}

Paul Nitze and the Tradition of Non-Use of Nuclear Weapons

Reid Pauly
Cornell University, 2010

Immediately following the first and only uses of the atomic bomb in Hiroshima and Nagasaki, President Truman described nuclear stewardship as "an awful responsibility that has fallen to us." The decision to use the bombs did clearly demonstrate the operational effectiveness of a new and awesome weapon, as the atomic bomb was generally accepted to have been critical in bringing about the Japanese surrender. Moreover, new weapon technologies have consistently been used in subsequent warfare throughout human history.i Policy-makers in the post-1945 period, therefore, would have had to work energetically against that precedent if they sought to meet Truman's "responsibility" and establish a tradition of non-use of nuclear weapons. This paper will defend the proposition that this is exactly what key American policy-makers sought and accomplished.

In the narrative that follows, the key dates to be examined are between 1945 and 1950-a transformative period in American foreign affairs when Paul Nitze and other key US policy-makers were setting the stage for the Cold War.iii The key to this study is not in episodically assessing why the United States repeatedly stepped back from the brink of the nuclear abyss, but rather in seeking to discern the development of a tradition of policy considerations concluding in the practice of nonuse..$^{v}$ This policy evolution is tracked through three key debates of the early Cold War: establishing the uniqueness of nuclear weapons, creating the hydrogen bomb, and the writing of NSC-68.

Scholars have proposed two key explanations for the widely unexpected legacy of atomic weapons: the tradition of non-use and the nuclear taboo. The taboo explanation stems from a constructivist appreciation of the role of ideas and social action in state behavior, while the tradition of non-use comes from an assessment of the material and reputational factors considered by rational and strategically-oriented policy-makers. Both of these explanations need to be taken into account when assessing the non-use of nuclear weapons. Overall, I argue in this paper that US nuclear policy, with the early support of policy-makers like Paul Nitze, developed in a way that allowed for the emergence of a tradition of non-use of nuclear weapons. Evolving practices in the early years of the Cold War contributed substantially to a strategic commitment that helped prevent the use of nuclear weapons and prepare the ground for later struggles against proliferation.

\section{Introduction}

On a rainy day in June 1982 , two men sat on a log in the forest outside of Geneva Switzerland. The topic of conversation was nothing less than the terms of a dramatic nuclear arms reduction pact between the United States and the Soviet Union. For weeks delegates from both nations had been butting heads at the negotiating table with little progress to show for it. Frustrated, and fearing the ultimate failure of this unusual opportunity to limit the scope of the furious
Cold War nuclear arms race, these two delegates departed from the confines of their retreat center for what would come to be known as "the walk in the woods." Seated face-to-face on a fallen tree, the two men from opposite sides of an iron curtain hashed out the details of a compromise between East and West. ${ }^{1}$

Far from the White House and the Kremlin, Paul Nitze and Yuli Kvitszinsky's frank discussion on that afternoon demonstrated that the unlimited proliferation of nuclear arsenals was not predestined, and that individuals long associated with unflinching commitments to nuclear strength could now seriously envision a world without the existence of threatening nuclear arms. The biggest surprise was on the American side, as Paul Nitze, a fixture of the US defense establishment since World War II and the hawkish author of NSC-68, had come to believe in the idea of completely eliminating nuclear weapons. His apparent turnabout was so unexpected that it begs the question of whether the United States had ever really been serious about using the nuclear weapons in its vast stockpile.

The non-use of nuclear weapons since their first use in Hiroshima and Nagasaki in 1945 is surprising in itself. ${ }^{2}$ Scholars have proposed two key explanations: the tradition of non-use and the nuclear taboo. The taboo explanation stems from a constructivist appreciation of the role of ideas and conceptions of identity in state behavior, while the tradition of non-use derives from an assessment over time of the material and reputational factors considered by rational and strategically-oriented policymakers.

This paper poses two related questions about the initial development of US nuclear weapons policy in the years just after the end of the Second World War. First, did policy-makers show in their deliberations or actions doubts about the use of nuclear weapons which might help us to explain the emergence of a tradition of non-use of nuclear weapons? Second, given his enduring role as nuclear strategist, policy advisor, and finally radical skeptic, could Paul Nitze himself have helped establish such a tradition from the earliest days of the Cold War? I explore these questions in this paper and will argue that the answers are in both cases affirmative.

and after he died Paul Nitze was often characterized by historians as a hawkish and militaristic government bureaucrat whose paranoia of Soviet expansionism drove him to view the international system in absolute terms and therefore consistently to advocate a forceful and aggressive US policy line. ${ }^{3}$ The common view is that he exacerbated the tensions between the United States and the Soviet Union, deepening the Cold War and more than once drawing the two sides close to direct hostilities. ${ }^{4}$ It typically reads too much into episodes at the brink of nuclear escalation and fails to consider the evolving, nuanced, and complex nature of strategic thinking in the deep background of decision-making. In contrast, this study seeks to discern the pattern of thought typified by Nitze that over time and across many presidential decisions solidified into a tradition of non-use, a tradition

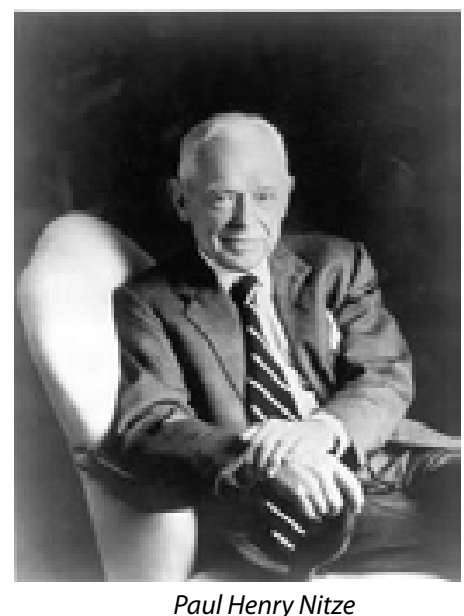

that does not make future use by the United States impossible but does raise the threshold of decision very high. ${ }^{5}$ The most important progenitors of this tradition, presidents and their key advisors, can hardly be labeled idealists. They were not scientists or policy advocates far removed from the lines of battle. At the beginning of the nuclear era, at any rate, they were hardened realists, tempered by war and capable of ruthlessness. To illustrate the complicated mind-set at the core of the evolving tradition of non-use this paper takes a fresh look at one particular policy-maker involved from the very beginning. 


\section{Paul Henry Nitze (1907 - 2004)}

Paul Nitze was a difficult man, not easy to like. He was a calculating and deft advisor, but not the most profound strategist of his time. For many decades, however, he was trusted by hard-nosed decision-makers and feared by adversaries. The record suggests that he was also deeply aware of the moral and ethical implications of his famously hawkish military stance, and that he worked hard to prevent the use of nuclear weapons by either superpower during the Cold War. Not the only contributor to the development of the non-use tradition, he was nevertheless deeply involved at three key historical moments:

Paul Nitze was often

characterized by historians

as a hawkish and militaristic government bureaucrat

when the earliest decisions were made to treat atomic weapons as unique, when the decision was made to build the hydrogen bomb, and when the National Security Council agreed on the operational underpinnings of a policy to contain the expansion of the Soviet Union.

On October $28^{\text {th }}, 1999$, Paul H. Nitze wrote his last and most unexpected op-ed article for The New York Times. In it he stated clearly: "I see no compelling reason why we should not unilaterally get rid of our nuclear weapons." ${ }^{\prime}$ Before his death in 2004, Nitze had reconciled his years of experience in nuclear policy-making with an argument for the complete denuclearization of the planet. How did he arrive at this conclusion, which, given his reputation as a foreign policy hawk, came as such a surprise?

As a young graduate of Harvard University, Nitze began his career on Wall Street. ${ }^{7}$ Working for the prominent investment bank Dillon, Read, and Company, Nitze survived the Great Depression and built a network that would sustain him for the rest of his life. Disciplined, diligent, and confident almost to the point of arrogance, he had made his reputation as a savvy economist and moved to Washington DC in 1940 with James Forrestal, the president of Dillon, Read and future US Secretary of Defense. ${ }^{8}$ He remained deeply engaged with policy from then until the administration of Ronald Reagan. ${ }^{9}$

Nitze first served as Vice Chairman of the United States Strategic Bombing Survey, which assessed the effectiveness of Allied bombing campaigns during the war. After a stay in Europe, he spent two months in Japan, becoming intimately familiar with the devastating carnage of the atomic bomb. In late November, 1945, he wrote home in a letter to his mother that his team had come to know "what happened to each ship, plane, shell, ton of coal, rodent, fly, open latrine, and house of prostitution during the course of the war."10 Nitze's sentiments towards Japan appear to have been marked with ambiguity at the time. He recollects in his memoir that "Japan was the most beautiful country I had ever seen. Then we got to the ground and could see just how devastating the war had been for Japan. Whole cities had been burned to the ground by the air raids..."11 Like most Americans, Nitze could not forget the tragedy of Pearl Harbor, and his memoir demonstrates this sentiment. "My own feelings were likewise confused," wrote Nitze, "I thought Japan was a marvelous country populated by the most hateful people on Earth."12 Nonetheless, in another letter to his mother, dated October $18^{\text {th }}, 1945$, he wrote about an encounter he had with some locals: The Japs themselves are certainly an extraordinary people. The peasant class are simple, gay, graceful, and hardworking While waiting for a guard to let us into an underground factory out in the hills, I gave some chocolate to a group of small children standing about. When we came out again they all had a few small chestnuts to give to me.

Going to Japan humanized the enemy for Nitze, and his later thinking would reflect this experience.

As the USSBS team worked indefatigably to complete their project by Christmas 1945, Nitze began to develop his own opinion of atomic weapons. His final report for USSBS concluded that their use had not been decisive in bringing about the Japanese surrender. "Based on a detailed investigation of all of the facts, and supported by the testimony of the surviving Japanese leaders involved," wrote Nitze in the report, "it is the Survey's opinion that certainly prior to 31 December 1945, and in all probability prior to 1 November 1945, Japan would have surrendered even if the atomic bombs had not been dropped, even if Russia had not entered the war, and even if no invasion had been planned or contemplated."14 Above all, Nitze's conclusion rested on his assessment that the atomic bomb was not an "absolute weapon" and that Japan could have continued its war effort even after the bombings. In the end, the report was discredited within the US military, in what Nicholas Thompson characterizes as a series of friendly fire attacks by military branches staking budgetary claims in the fraught atmosphere of postwar reorganization..$^{15}$ Nitze, however, never repudiated the conclusions to which the USSBS team had come.

Just as the actual conception of nuclear weapons presented a new challenge to military routines, associated strategic thinking had to develop outside of conventional idealist-realist analytical frameworks. It was in just such an environment that Nitze first wrestled with the American burden of nuclear arms. His strategic views developed within a flexible and fluid framework of nuclear policy ideas that in part diverged from his generally hawkish stance. In short, he functioned within a grey area that provided him the intellectual leeway to side with the military establishment and promote nuclear armament, and at the same time work diligently to prevent the use of nuclear weapons by any nation. For example, Nitze famously argued for a policy of 'graduated deterrence' rather than 'massive retaliation. ${ }^{\prime 16}$ In a 1956 article in Foreign Affairs, entitled 'Atoms, Strategy, and Policy', Nitze made the following recommendations for a policy governing the use of atomic weapons by United States:

(a) We should endeavor to meet aggression and restore the situation without the use of atomic weapons wherever this is possible.

(b) We should extend hostilities to other areas only if there is no other way effectively to restore the situation.

(c) Even if it becomes necessary to engage the U.S.S.R. in atomic warfare, we should limit ourselves to military objectives, primarily to those which are necessary to achieve control of the air. We should not initiate the bombing of industrial or population centers.

(d) population centers.

(d) We should attempt to build non-atomic elements of strength and to encourage our allies to do likewise so that the residual reliance which must be placed upon atomic weapons for our common security is reduced as far as may be feasible. ${ }^{17}$

These do not seem like the policy recommendations of a recalcitrant hawk. In fact, the implication of these recommendations is even more dovish than historians have generally acknowledged, for they all point to one long-term hope: nonuse. Nitze's oral histories also reflect these sentiments, referring to his abhorrence of nuclear weapons on numerous occasions. ${ }^{18}$ Accordingly, with others of a similar mindset he helped guide the United States through its formative nuclear years, allowing the practice of non-use of nuclear weapons to develop and eventually establish a recognizable tradition.

\section{Establishing the Uniqueness}

of the Bomb

Within a fortnight of taking office in April 1945, Harry Truman was briefed by Secretary of War Henry L. Stimson on the atomic bomb. ${ }^{19}$ During the briefing Stimson did not cut any corners in addressing the global significance of the new technology, and in the process he may well have traumatized President Truman. Stimson's presentation emphasized six main points. First, the United States would soon possess the technology to destroy an entire city with a single bomb. 
Second, the US would not remain the sole possessor of the bomb in the future and that adversaries could use it to unleash devastating surprise attacks. Third, this new weapon might lead to the complete destruction of modern civilization. Fourth, international controls should be sought to limit the bomb's use. Fifth, the United States now had a moral responsibility to protect the civilized world from nuclear obliteration. Sixth, if the bomb was properly handled the US might be able to

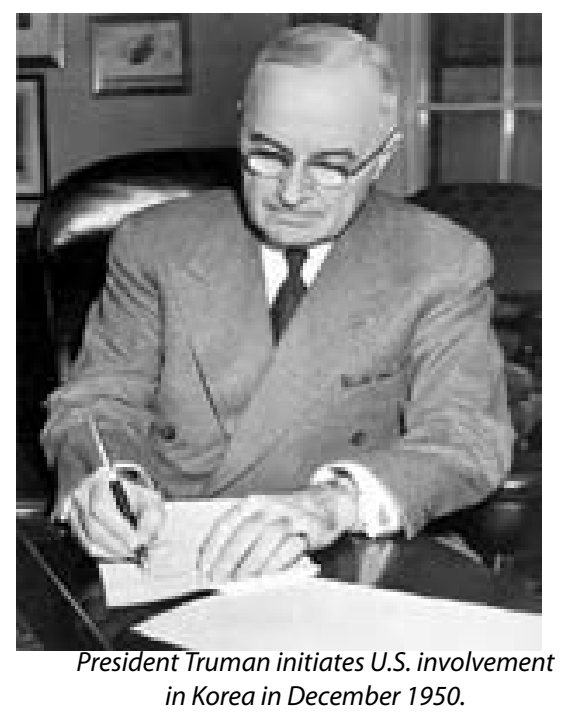

not only save civilization, but ensure the peace and stability of the world. ${ }^{20}$ It seems that Truman made the subsequent decision actually to use the bombs on Japan in something of a haze of incomprehension, treating their use as rather a foregone conclusion. With the fierce Battle of Okinawa also fresh in the minds of American officials, the prospect of vast casualties resulting from an invasion of the Japanese mainland made use of the atomic bomb obviously appealing. ${ }^{21}$ "Having found the bomb we used it," stated Truman flatly in a radio address on August $9^{\text {th }}, 1945$, after the bombing of Hiroshima. ${ }^{22}$ Nevertheless, Truman did not forget Stimson's message in the weeks following the conclusion of the Pacific War, and he soon began to work in earnest to limit the acceptability of the atomic weapon.

To begin with, Truman himself accepted sole responsibility for authorizing any use of atomic force; in doing so, he established a powerful pre presidential control over the US nuclear machinery. ${ }^{23}$ He also demanded that nuclear weapons be kept separate from conventional weapons in the US military arsenal. ${ }^{24}$ On top of this separation of armaments, Truman pushed the formation of the Atomic Energy Commission through Congress in 1946 to place nuclear weapons and material under the control of civilian leadership. When the Atomic Energy Commission was created in 1946, custody of the atomic bomb was handed over from the Army to civilian oversight. ${ }^{25}$ Truman, believing the bomb to be of unique importance, separated it from the traditional mechanisms of conventional weapons consideration. "The release of atomic energy," Truman would say at the time, "constitutes a new force too revolutionary to consider in the framework of old ideas." ${ }^{26}$ This decision to place atomic bomb use under civilian control was contested by military leaders and the Secretary of Defense, James Forrestal, who continually requested military custody up to and even after the decision to establish the AEC. ${ }^{27}$ By creating the civilian-led AEC, Truman effectively preempted military leadership in nuclear weapons policy-making, and established a bureaucratic check on military decision-making.

With his work on USSBS and then on the Marshall Plan, Nitze did not play a central role in the creation of the Atomic Energy Commission. Nonetheless, he was a witness to the early debates between military and civilian leaders and followed closely the changing conception of nuclear weapons in American foreign policy. That conception legitimized the work of civilian leaders overseeing nuclear materials and also laid the groundwork for civilian input on decisions about the use of atomic force. As a result, for example, civilians in the executive and legislative branches would later find it within their mandates to oppose the creation of a neutron bomb and ban peaceful nuclear explosions in the United States. ${ }^{28} \mathrm{Had}$ the field of atomic energy been developed early on within a framework of military decision-making, later civilian support of the practice of non-use may well have had less of an impact on policy.

\section{The Hydrogen Bomb}

Since 1943, at the dawn of the nuclear revolution, scientists had considered the feasibility of developing a fusion bomb. ${ }^{29}$ According to historians Samuel Williamson and Steven Rearden, problems with uncertain theoretical probabilities, possible detrimental effects on the environment, and estimates of astronomical costs initially stood in the way of actually pursuing its development. ${ }^{30}$ But on August $29^{\text {th }}, 1949$, something entirely unexpected occurred in Semipalatinsk, Kazakhstan-the Soviet Union tested its own bomb. It wasn't until six days later that an American B-29 flying north from Japan noticed that radiation levels in the air were too high to be normal. ${ }^{31}$ So in the autumn of 1949 Washington DC was all abuzz about how to respond. The decision was soon made to unleash the power of the fusion reaction.

On November 19, 1949, President Truman ordered the formation of a special committee consisting of Secretary of Defense Louis Johnson, Secretary of State Dean Acheson, and David Lilienthal to advise him on the creation of fusion technology-it was called the Z Committee. ${ }^{32}$ As it turned out, Acheson and Johnson delegated the task to their subordinates, and thus a sub-committee was formed of Paul Nitze from the State Department, Robert LeBaron from the Defense Department, and Lilienthal from the AEC. ${ }^{33}$ Given that the AEC was strongly opposed to creating a hydrogen bomb, and the Defense Department was in favor, the swing vote landed squarely in the lap of Paul Nitze. ${ }^{34}$ The committee discussed matters of feasibility necessity, and above all the implications of a fusion bomb in light of the Soviet threat.

On December 19, 1949, Nitze penned a memo supportive of taking the next step..$^{35}$ He clarified that his recommendation was for continuing research to determine the feasibility of creating a fusion reaction, and not necessarily to construct a weapon should related experiments succeed. ${ }^{36}$ The memo also contained a clear recommendation as to the necessity of a reexamination of US policy in the Cold War, preceded by a statement of belief that "emphasis by the US on the possible employment of weapons of mass destruction, in the event of a hot war, is detrimental to the position of the US in the Cold War." ${ }^{\prime 3}$

On the one hand, it seems as though Nitze wanted to avoid pushing the United States towards accepting the eventuality of nuclear use. On the other, he was advised by Secretary Acheson that"the NSC subcommittee probably should not direct its efforts toward the ultimate moral question at this time but should express as much fact and analysis as possible..." 38 In the same memo, dated December $3^{\text {rd }}, 1949$, Acheson also expressed his misgivings about nuclear use. Under Secretary of State James Webb later credited Acheson with saying, "Somewhere, we should make a review of what we have said about not using atomic weapons and about controls. At the same time, review what has been said by the military with respect to its plans to use the weapon." 39 Indeed, both Acheson and Nitze seemed especially concerned with ensuring that any steps toward weaponizing the fusion reaction should not be mistaken as an act of war or as a statement of readiness by the United States to use the weapon in battle. Ultimately, Nitze and his sub-committee came down in favor of the hydrogen bomb project. They gave it the green light but also insisted that it be accompanied by the complete reexamination of US foreign and security policy in light of the new weapon. ${ }^{40}$ That task, as it turned out, would fall again onto Nitze's lap and culminate in his drafting of NSC-68.

Nitze appears to have viewed the super bomb the same way that President Truman eventually did-as constituting a 
nuclear game of chicken, potentially blocking the path of international cooperation. ${ }^{41}$ When the $Z$ Committee met with President Truman on January $31^{\text {st }}, 1950$, after over three months of deliberation, the meeting was reported to have taken only seven minutes. ${ }^{42}$ Truman asked only one question of the committee: "Can the Russians do it?" ${ }^{\text {43 }}$ In the

Nitze appears to have viewed the super bomb the same way that President Truman eventually didas constituting a nuclear game of chicken, potentially blocking the path of international cooperation.

end, the decision to forge ahead with nuclear experimentation waslessaggressivethan itwas necessary. According to his biographer, David McCullough, Truman even took a moment to explain his thinking to David Lilienthal, who was the most distraught over the President's decision. During the January $31^{\text {st }}$ meeting Truman leaned over to the AEC Chairman and said "he had always believed the United States should never use 'these weapons,' that peace was 'our whole purpose."'t4 Nitze didn't hear that remark, but the record of his thinking reflects similar sentiments. By extension of both Nitze and Truman's logic, building a hydrogen bomb seemed, paradoxically, the best way of actually avoiding the use of nuclear weapons. Nitze, who was concerned with eliminating incentives for surprise attack, desired the United States to always have a slight nuclear advantage over the Soviet Union, thereby encouraging a tense stability between the two powers.

\section{NSC-68}

History remembers Paul Nitze mainly as a hawkish cold warrior. For example, Andrew Bacevich notes that the "Nitze Doctrine offered a recipe for the permanent militarization of US policy."45 That Doctrine was most explicitly framed in National
Security Council Memorandum \#68, drafted while he was director of the Policy Planning Staff at the State Department. Written in 1950 and declassified in 1975, NSC-68 relied heavily upon then-dominant perceptions of the threat from the Soviet Union and the ideological incompatibility of capitalism and communism. Nitze's own grim outlook on such matters prompted him to seek more military spending. In perhaps its most quoted sentence, NSC-68 laid down a policy of initiating "a substantial and rapid build-up of strength in the free world...to support a firm policy intended to check and roll back the Kremlin's drive for world domination." ${ }^{46}$

The document was meant to provide a holistic review of US foreign policy in light of recent developments, including the possibility of the hydrogen bomb and the Soviet possession of the atomic bomb. Although it omitted actual dollar amounts, NSC-68 called for a dramatic increase in military spending, which totaled $\$ 13$ billion in $1951 .{ }^{47}$ In fact, between $\$ 35$ and $\$ 50$ billion would be spent annually over the next few years. ${ }^{48}$ The increased funding was meant to strengthen US military capabilities through and through, including both nuclear and conventional forces.

In short, NSC-68 militarized the US Cold War policy of containment. But it did something for the United States that has been largely overlooked. By increasing military spending on conventional and nuclear forces, the policy shift advocated in NSC-68 pushed the US off the course of complete reliance on nuclear weapons. Moreover, by committing the United States to investing in the policy of containment, it shifted the discussion away from the singular option of a first-strike against the Soviet Union, effectively moving policy away from the idea of a preventive nuclear war and opening the door to the intentional practice of not actually using nuclear weapons.

Between 1947 and 1949, preventive war against the Soviet Union was in fact seriously contemplated at the highest levels of the US government. Many strategic considerations lay in the background, ranging from the need to prevent the Soviet Union from obtaining an atomic bomb to hitting an existential enemy while the US was still in a position of strategic and military advantage. Given that military planning was rooted in a mentality of war-winning, planners often ascribed to the continuity school of nuclear weapons and incorporated the use of the

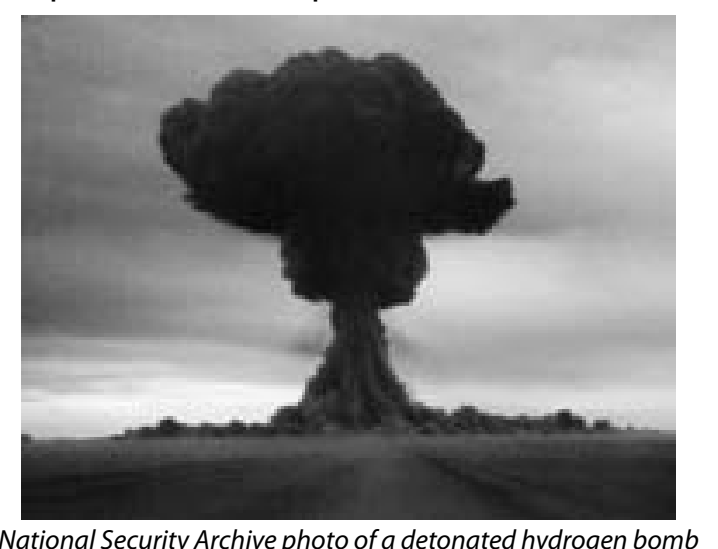

bomb in tactical battle preparations. Between April and June 1946, four draft war plans were produced that included "prompt strategic air offensives" aimed at destroying "Soviet warmaking capabilities." 49 While the US held a monopoly on atomic weapons, the bomb factored heavily in the perceived effectiveness of these proposed strikes. After 1949, moreover, the US war plans concentrated on a preemptive nuclear tactic of "blunting" the enemy's capability of delivering its ultimate weapon. ${ }^{50}$

As Scott Sagan points out, US military leaders pushed more for a preventive nuclear war than civilian leaders did..$^{51}$ Many famous Generals, including Kenney, LeMay, Power, Twining, White, and Vandenberg sympathized with preventive war doctrines. ${ }^{52}$ In a September 1945 report on post-war military organization in the US, the Joint Chiefs of Staff was explicit in this regard: "When it becomes evident that forces of aggression are being arrayed against us by a potential enemy, we cannot afford, through any misguided and perilous idea of avoiding an aggressive attitude to permit the first blow to be struck against us."53 Such an idea seems to have been of incredible importance to other policy-makers, who sought to avoid the use of atomic weapons. The evidence suggests that Nitze would have taken issue with this statement as well, but not merely because of its implications for nuclear use. Nitze would simply have rejected the notion that preventive war was required in order to avert a first-strike on the United States. On the contrary, he took a stance against preventive war in NSC-68, and worked through other means, like deterrence through denial, at eliminating the original incentives for a nuclear surprise attack. NSC-68 should be seen as a response to the generals. Its aim was to diminish the threat of nuclear war and to stop nuclear weapons from being used.

In his memoir Nitze states that, "one of our first concerns [in NSC-68] was the security of Europe. ${ }^{\prime \prime 4}$ This complements his recollection that he was most afraid of nuclear weapons deployment occurring over Berlin in 1948, not over Cuba in 1962 or any other Cold War crisis.55 The idea of not backing the United States into a corner by relying on nuclear weapons had actually occurred to Nitze early on. In an October $11^{\text {th }}, 1949$ meeting of the Policy Planning Staff, Nitze asserted that the recent Soviet acquisition of atomic weapons would make "conventional armaments and their possession by the Western European nations, as well as ourselves, all the more important.".56

In his oral history, Nitze claims that Truman supported NSC-68 all the way, but did not think that it was necessary to spend "all of that money. ${ }^{157}$ Nitze made a great effort to try persuading Truman, but it was the Korean War that ultimately moved policy decisively along the NSC-68 line..$^{58}$ Shortly after the release of NSC-68, the United States considered using atomic weapons against both North Korea and China. ${ }^{59}$

On November $30^{\text {th }}, 1950$, President 
Truman held a disastrous press conference on the situation in Korea. Upon being pressed by several reporters, Truman declared that the atomic bomb was under active consideration for use, and that military field commanders would be responsible for deciding whether to use it or not. ${ }^{60}$ The statement was untrue, but negative reaction was immediate. Upon hearing of the President's public proclamation, British Prime Minister Clement Attlee flew to Washington to meet with Truman personally, imploring him not to use nuclear weapons in Korea. The whole incident was a public relations mess for the White House. Nonetheless, what is most interesting is that Truman must have known what he was saying was incorrect, since he was well aware of his own personal role in permitting the use of atomic weapons. It is possible that in that moment, Truman knew he needed to maintain a public position of strength with regard to the credibility of the American nuclear deterrent. In a way, Truman was forced into his unfortunate answer by acknowledging that he could not publicly declare that he was not considering the use of nuclear weapons in the Korean War. If he had made a statement about the sheer abhorrence of nuclear use and an American desire not to use nuclear weapons, then the credibility of the US nuclear deterrent would be diminished in the eyes of the Soviet Union. In this way, Truman perhaps inadvertently and certainly inelegantly gave voice to the spirit of NSC- 68 .

On November 4, 1950, Nitze wrote a memo to Secretary Acheson about considerations for the use of atomic weapons in Korea. He concluded that if a bomb were to be used for tactical purposes on only military targets, the civilian damage would be minimal and it could prove effective for the UN mission. ${ }^{61}$ However, he urged against any such action. Given that the US military was in Korea under the auspices of the United Nations, be pointed out that using the bomb would have "world-wide repercussions" that could "leave us in a disadvantageous moral position." ${ }^{62}$

Afewyearslater, Nitzealso disapproved of the use of atomic weapons to defend the islands of Quemoy and Matsu off the coast of China. ${ }^{63}$ After Eisenhower backed away from his original 1958 plan to use nuclear weapons, Nitze attended a meeting with Senator Bill Fulbright (D-AR), who turned to Nitze at one point and said, "You know, Paul, I wish the President had stayed with his decision to use the nuclear weapons." "Good God, Bill," replied Nitze, "you can't really be serious about that!"64 As it turns out, Senator Fulbright was merely curious about what would have happened, but his inquisitiveness had struck a chord of disdain in Nitze. Around the same time, Nitze told Dean Acheson, then former Secretary of State, that it was an "asinine" idea to use nuclear weapons to defend Taiwan.

In 1957, the Gaither Report explicitly rejected the policy of preventive war by the United States. ${ }^{66}$ Nitze was a member of the Gaither Committee and supported its conclusions, conclusions that were consistent with his thinking for many years. He remained a conventional hawk, and while he never completely foreclosed the possibility of using the bomb but he felt that irresponsible nuclear stewardship was "immoral."67 His policy recommendations in the early days of the nuclear era fell short of explicitly advocating non-use, but he also never tried to establish the conditions under which reliance on nuclear force would be acceptable. These subtle policy distinctions, rooted in a rational appreciation of materialist and reputational considerations, helped guide the United States down a path of non-use and construct the tradition as we can now perceive it.

\section{Conclusions}

An examination of nuclear policy decisions made by early post-war policymakers suggests that decades of nuclear peace have not been the product of sheer good fortune. The case of Paul Nitze in particular demonstrates that even decidedly hawkish presidential advisors had nuanced and complex worldviews. By establishing the uniqueness of nuclear weapons in both military and civilian terms, the Truman administration not only provided credence to the view of nuclear weapons as radically discontinuous innovations, but also rejected decisively the idea that military planners should control them. In addition, the debate over the creation of the hydrogen bomb, while ending in a decision to develop fusion technologies, left an enduring legacy of careful deliberation and a strong tendency to consider the new arsenal as useful only for purposes of deterrence and not for actual deployment. Finally, linked to the hydrogen bomb decision and to this day commonly viewed as needlessly bellicose, NSC-68 supported a policy inclination not to use nuclear weapons, even in adverse strategic circumstances, and it helped delegitimize the idea of preventive nuclear war.

For policy-makers like Paul Nitze, it was possible to threaten nuclear retaliation and at the same time to erect a very high barrier to the use of nuclear weapons. Over time this complex position helped establish a tradition of non-use. Traditions can be overturned, of course, but once recognized, they raise the threshold for contrary decisions. In short, they constructed a routinized normative framework aimed at constraining, informing and guiding behavior. Future policy-makers are not entirely bound, but they are influenced. The weight of history lies heavily on their shoulders.

With regard to the possible use of nuclear weapons, we continue to live on

Figure: The Emergence of the Tradition of Non-Use

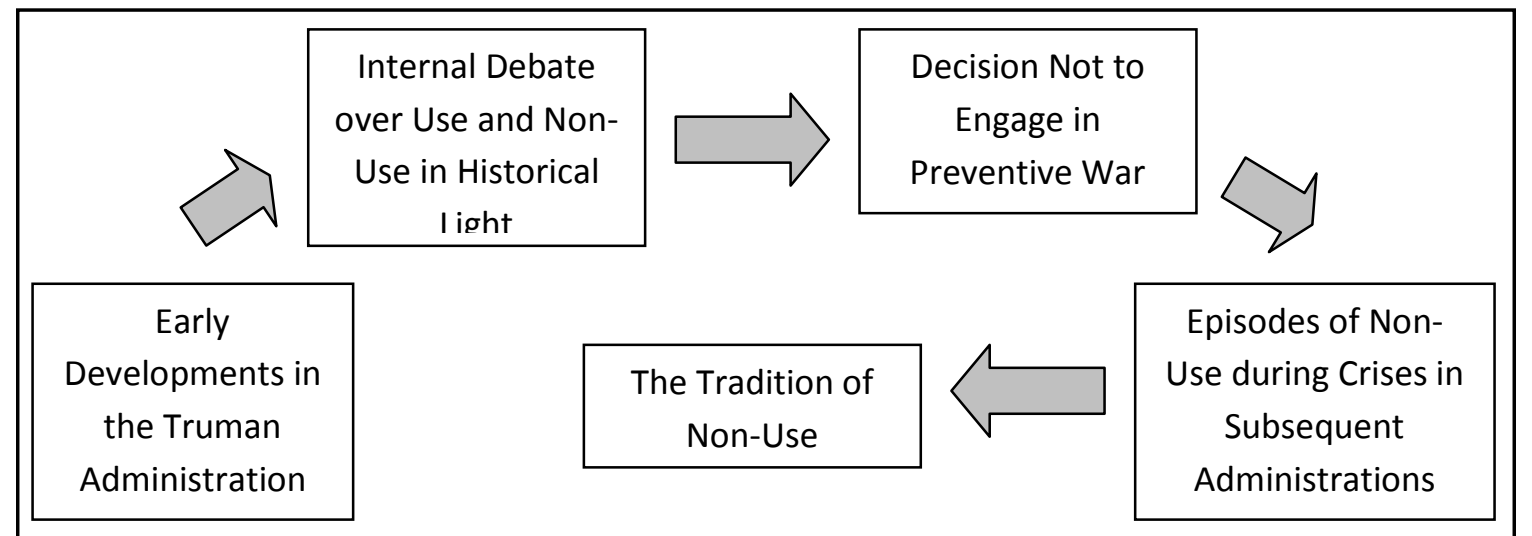


importance of doves like George Kennan, who energetically opposed the development of nuclear technologies, especially the hydrogen bomb in 1949.71 Like others who helped shape the social context within which nuclear questions would later be answered, Kennan believed that reliance on nuclear weapons would make it "difficult if not impossible to do anything else [but use them] when the time [came] to make a decision."72 A preemptive declaratory policy of no-first-use was therefore Kennan's own answer to the nuclear dilemma. ${ }^{73}$ Nitze disagreed with that solution, and it is precisely this disagreement combined with his acquiescence in unspoken decisions not to use nuclear weapons that carried the Endnotes

ANOTE ONSOURCES

Much of the evidence presented in this paper comes from primary sources. Full references are provided in a thesis on file in the Govermment Department, Cormell University. Most
government documents from the early days of the Cold War have now been declassifed and are available for public viewing. There are many more documents available than I I have

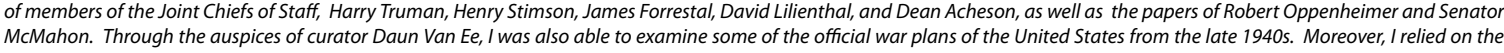

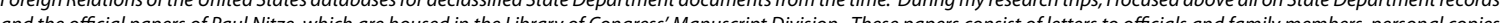

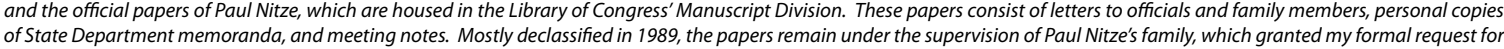
access John Lewis Gaddis et al Cold War Statesmen Confont the Bomb (New York Oxford University Press, 1999) 21.

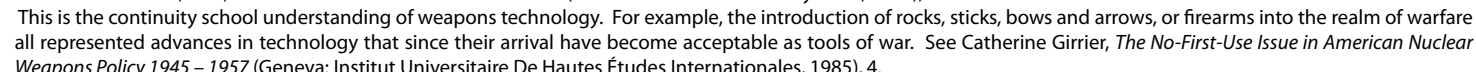

iii This relatively short time-frame may appear to o be an unfair test of the theory yf a nuclear taboo, since social taboos take time to develop. Nonetheless, if evidence for the emergence of a tradition of non-use can be found in this period, then the tradition may be presented as a more pla

Although the actions of other nations like the Soviet Union could have alas dramatically altered the history that we are studying, and are equally important in addressing
the question of global nuclear peace, this is fundamentally a study of US policy decisions reagrding the use of not establishment of an American tradition of non-use.

Nicholas Thompson, The Hawk and the Dove: Paul Nitze, George Kennan, and the History of the Cold War (New York: Henry Holt, 2009), 287. Steven Kull, Minds at War: Nuclear Reality and the Inner Conflicts of Defense Policymakers (New York, NY: Basic Books, 1988), 10; David Callahan, Dangerous Capabilities Ibid. Although the actions of other could have also dramatically altered the context of decision and
this study intentionally focuses only on the establishment of an American tradition of non-use. Paul Nitze, "A Threat Mostly to Ourselves," The New York Times, October 28,1999, , Opinion section.

Thompson, Hawk and Dove, 2 .

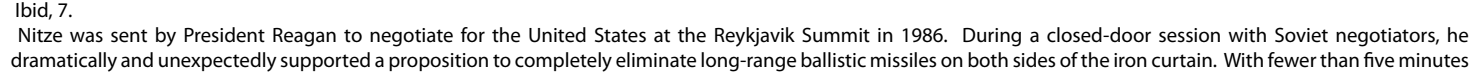
Ift in the meeting to discusss the proposition, little came of it.. Nitze Memoir Interviews with Steven Rearden and Ann Smith, 1982-1988, Paul Henry Nitze Papers, box 120 ,

10 folder 6 , Manuscript Division, Library of Congress.

appendix.
Nitze, Hiroshima to Glasnost, 38.

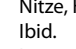

Letter from Paul Nitze to his mother, October 18, 1945, Paul Henry Nitze Papers, box 165, folder 5, Manuscript Division, Library of Congress.

bid.
Paul N

|bid, 196, Atoms, Strategy, and Policy"Foreign Affairs 34, no. 2 (1956): 187

Nitze Memoir Interviews with Steven Rearden and Ann S
Gaddis, et al. Cold War Statesmen Confront the Bomb 16 .

Ibic

Sean Malloy, Atomic Tragedy: Henry Stimson and the Decision to Use the Bomb Against Japan (Ithaca, NY: Cornell University Press, 2008), 99.

Mccullough, Truman, 395.

23 bid. 442 .

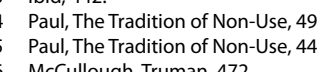

McCullough, Truman, 472.
Tannenwald, The Nuclear Taboo, 267

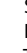

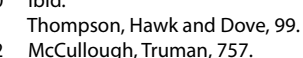

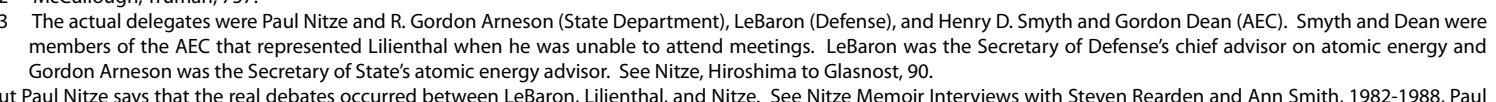

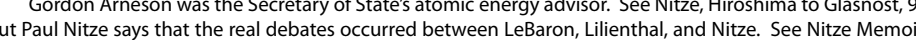

US Department of State, Foreign Relataions of the United States: National Security Affairs; Foreign Economic Policy, 1949 (Washington, DC: GPO, 1976), 610

36 Ibid, 611

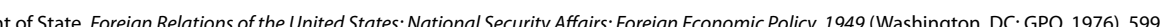

39 Ibid.

Ibid, 91

Weorge Bundy, who was not in government at the time of the hydrogen bomb decision, wrote an article for the New York Review of Books on May 13, 1982 called "The

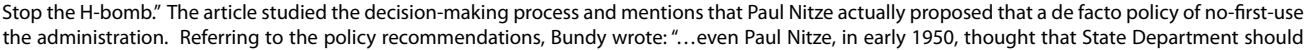

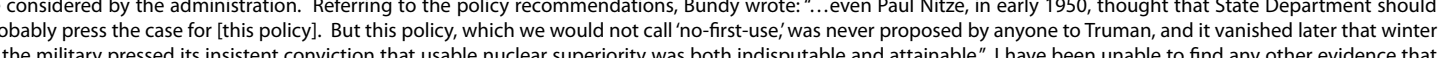

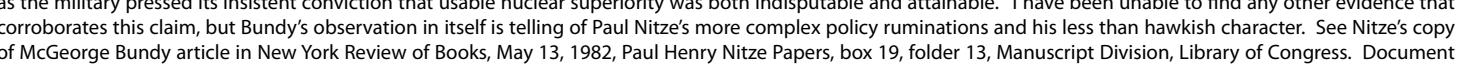
reprinted in the appendix.
McCullough, Truman, 762 .

Ibid, 763.

45 Andrew Bacevich, , the Limits

(W. Washington. DC. GPO, 1976)

49 Gentile, "Planning for Preventive War," Joint Force Quarterly, 69

Scot STagn and Kenneth Waltz, The Spread of Nuclear Weapons:A Dehate (New York, NY.W.W. Norton, 1995) 57.

$\begin{array}{lll}52 & \text { lbid, } 59 . \\ 53 & \text { lbid, } 58 .\end{array}$

Nitze Memoir Into lassnost, 93 Steven Rearden and Ann Smith, 1982-1988, Paul Henry Nitze Papers, box 120, folder 12, Manuscript Division, Library of Congress

Us Department of State, Foreign Relations of the United Sndes.W

59 Nina Tannenwald believes that various State Department memoranda pointed to the "special horrifying status" of nuclear weapons in order to recommend non-use of the "D use it must meet a more demanding test" Tannenwald The Nuclear Taboo, $120-121$.

60
61 Mccullough, , Trumann,, 22
6 US Depart

61 us D

Nitze Meole's Republic of China did not test an atomic bomb until 1964

Thid Tho not backed up by the actual intention of use. President Eisenhower's reconsideration of using nuclear weapons to defend Taivan in 1958 is a good example of such discrepancy between threat and intention. In discussion with author, January 18, 2010

6 , Manuscript Division, Library of Congress.

68 President Obama announced on April 5,2010 that the United States would be changing its declaratory policy regarding the use of nuclear weapons. He has promised that in the futurur the United States would not use nuclear weapons against non-nuclear powers, with the exception of states threatening tou use other kinds of weapons of

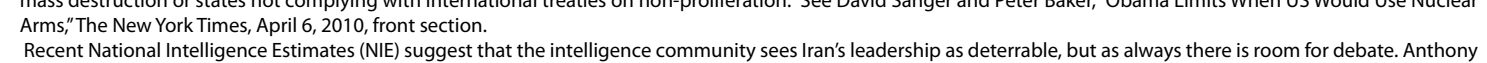

69 Recent National Intelligence Estimates (NE) suggest that the intelligence community sees Iran's leadership as deterrable, but as always
Cordesman,"Iran and the US: Key Isues from an American Perspective" Center for Strategic and International Studies, January 3, 2008.

70 Prof. Thomas Schelling (UMD), in discussion with author, January $18,2010$.

$\begin{array}{ll}71 & \text { Thompson, Hawk and Dove, } 106 . \\ 72 & \text { Williamson and Rearden, Origins of US Nuclear Strategy, } 117 .\end{array}$

\section{Bibliography}

Primary Sources

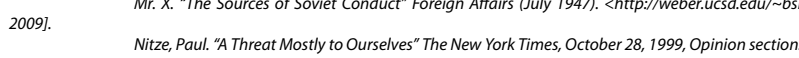

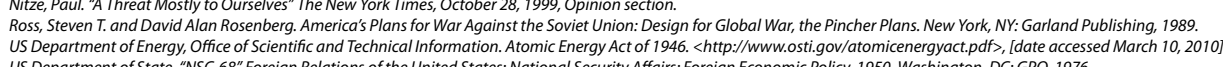

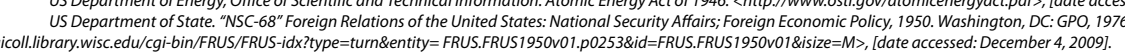

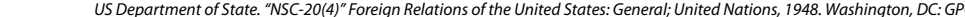

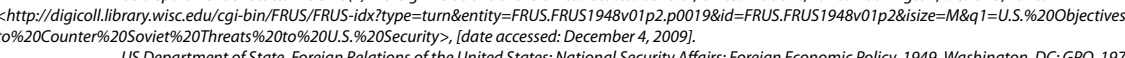

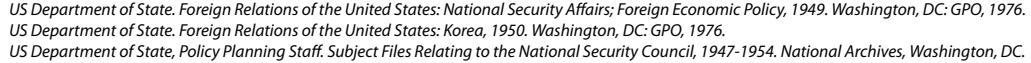

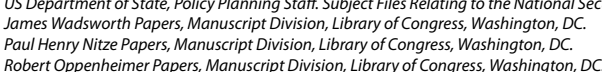

Books 
Websites

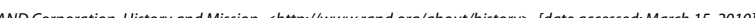

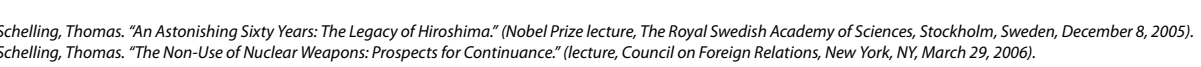

Personal Interviews

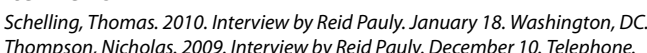

Thompson, Nicholas. 2009. Interview by Re Reid Pauly. December 10. Telephone.
Adler. Emmanuel. 2010. Interview by Reid Pauly. January 8 . Toronto, ON.

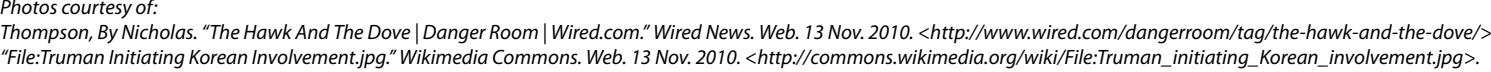

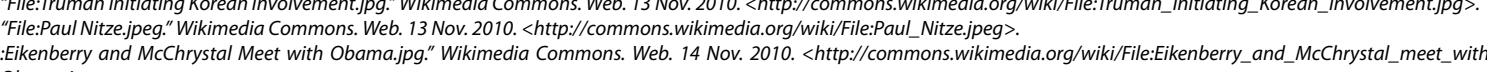
:Eikenberry an
Obama.jpg.

successors.

The Public Sphere's

\section{Private Intelligence}

aqu

\section{Peter Gruskin}

MA Candidate, Middle East Studies, 2011

Peter Gruskin is a free-lance author and graduate student at Johns Hopkins School of Advanced International Studies (SAIS). He has completed a book of 60 essays on the War on Terror as well as a monograph on U.S. intelligence policy. Peter is studying the Middle East, with a focus on the Afghanistan-Pakistan conflict and Iran.

Supporters of "green-badgers"-the nickname given to contractors working inside the American intelligence community-argue that after 9/11 the United States needed a more flexible labor pool of intelligence professionals todraw on, and so a large number of contractors was needed for the monumental task at hand. Since 2001, the surge in green-badgers has been proportionate to the security needs of the War on Terror, say supporters. With attacks abounding in the various theatres of war abroad and even domestically, the U.S. government needed a backup security force as well as support for high-technology products that only the private sector could provide. Many private citizens, some of whom had left the intelligence community years before, were already "cleared," and the political incentives were already in place to increase funding for non-governmental assistance to classified work. It was an opportunity to broaden the abilities of various agencies-technical and human in their needs-to make American defenses stronger.

Morecritical and theoreticalarguments start with the rule of law. Consider Office of Management and Budget (OMB) memo A-76, which calls for the U.S. intelligence leadership to keep in its federal control all matters relating to "inherent government tasks." responsibilities, according to many experts, are the managing of the "overall direction" of intelligence policy at home and abroad and the implementation of counterintelligence these two conditions have not been met, in the sense that American telecommunications companies were participants in the domestic wiretap program initiated by the George W. Bush administration, and because intelligence corporations $\mathrm{CACl}$ and Blackwater were involved in torture in Iraq at Abu Ghraib² and in Baghdad's Nisor Square ${ }^{3}$ respectively. Such a position notes that even supporters of intelligence outsourcing have called for a slashing of their numbers by $10 \%$, and that reform is obviously necessary on this core national security issue.

Naturally, both sides of the debate little agree when it comes to policy implementation, but one thing remains accepted by opponents and supporters of contractors in the U.S. intelligence community: intelligence 9/11. ${ }^{4}$ Regardless, it did accelerate at this time. Through at least as far back as the Vietnam War, through the Clinton administration, we can locate contractors in military and intelligencerelated defense work. The Lockheed Company assisted in the manufacture of the U-2 spy plane in the 1950s and private contractors were thereafter used consistently in American the Clinton years, "outsourcing" and the "privatization of non-governmental functions" came to be known as terms specific to the work. Unfortunately, there is evidence that outsourcing was not a new phenomenon after military affairs during the Cold War. During 